UDC 621.3 .051

\title{
Improving the Energy Performance of Traction Electric Drive Vehicles in Solving Electric Braking
}

\author{
V. Herasymenko ${ }^{1)}$, N. Shpika ${ }^{1)}$, M. Smyrnyi ${ }^{1)}$, D. Khuruzha ${ }^{1)}$ \\ ${ }^{1)}$ O. M. Beketov National University of Urban Economy in Kharkiv (Kharkiv, Ukraine) \\ (C) Белорусский национальный технический университет, 2021 \\ Belarusian National Technical University, 2021
}

\begin{abstract}
The effectiveness of the electric braking system largely depends on how the braking is carried out, whether the braking characteristics that it forms are acceptable for a given vehicle, how simple and reliable the technical solutions embedded in the system are, and where the braking energy is used. With electric braking, it is possible not only to extinguish the electrical energy on the braking resistor, but also to send it back to the storage device and again use it in traction mode. This paper analyzes the most common methods of electric braking used in electric braking systems for traction electric drives that are in operation on vehicles. As the main criterion for evaluating the method of electric braking, its energy indicators are selected. The results of scientific research of the proposed new method of electric braking, which provides better energy performance and new technical solutions for its implementation, are considered. When implementing this method, DC motors are operated by sequential excitation generators. The current in the field windings is regulated by a DC-DC-converter. Energy in the power circuit is accumulated in storage devices and used in traction mode. When the storage devices are filled, the energy in the power circuit is extinguished by the braking resistor, and the energy from the output of the DC-DC-converter is used for own needs. In this case, braking characteristics are formed as in generators of independent excitation. To increase the braking efficiency at low speeds, it is necessary to smoothly regulate the resistance of the braking resistors by shunting them with transistor switches.
\end{abstract}

Keywords: transport, traction electric drive, electric braking, electric motor, DC-DC-converter, brake resistor

For citation: Herasymenko V., Shpika N., Smyrnyi M., Khuruzha D. (2021) Improving the Energy Performance of Traction Electric Drive Vehicles in Solving Electric Braking. Science and Technique, 20 (1), 52-57. https://doi.org/10.21122/2227$1031-2021-20-1-52-57$

\section{Повышение энергетических характеристик тяговых электромобилей в решении проблемы электрического торможения}

\author{
Магистр техн. наук В. Герасименко1), канд. техн. наук, доц. Н. Шпика'), \\ докт. техн. наук, проф. М. Смирный' ${ }^{1}$, Д. Хуружа ${ }^{1)}$
}

${ }^{1)}$ Харьковский национальный университет городского хозяйства имени А. Н. Бекетова (Харьков, Украина)

Реферат. Эффективность системы электрического торможения во многом зависит от того, каким способом оно осуществляется, приемлемы ли для данного транспортного средства тормозные характеристики, которые она формирует, насколько просты и надежны технические решения, заложенные в систему, и куда используется энергия торможения. При электрическом торможении можно не только гасить электрическую энергию на тормозном резисторе, но и отдавать обратно на накопитель и снова использовать в тяговом режиме. В статье проанализированы наиболее распространенные способы электрического торможения, применяемые в системах электрического торможения тяговых электроприводов, которые находятся в эксплуатации на транспортных средствах. В качестве основного критерия при оценке способа электрического торможения выбраны его энергетические показатели. Рассмотрены результаты научных исследований предложенного нового способа электрического торможения, обеспечивающего лучшие энергетические показатели, и новые технические решения его реализации. В случае применения указанного способа электродвигатели постоянного тока работают генераторами последовательного возбуждения. Ток в обмотках возбуждения регулируется с помощью преобразователя постоянного тока. Энергия в силовой цепи накапливается в накопителях и используется в тяговом режиме. При заполнении накопителей энергия в силовой цепи гасится на тормозном резисторе, а энергия с выхода преобразователя постоянного тока используется для собственных нужд.

\begin{tabular}{ll}
\hline Адрес для переписки & Address for correspondence \\
Герасименко Виталий & Herasymenko Vitalii \\
Харьковский национальный университет & O. M. Beketov National University \\
городского хозяйства имени А. Н. Бекетова & of Urban Economy in Kharkiv \\
ул. Маршала Бажанова, 17, & 17, Marshal Bazhanov str., \\
61002, г. Харьков, Украина & 61002, Kharkiv, Ukraine \\
Tел.: +38 099 388-30-28 & Tel.: +38 099 388-30-28 \\
Twixvi@gmail.com & Twixvi@gmail.com
\end{tabular}


При этом формируются тормозные характеристики, как у генераторов независимого возбуждения. Для повышения эффективности торможения в области низких скоростей необходимо плавно регулировать сопротивление тормозных резисторов путем шунтирования их транзисторными ключами.

Ключевые слова: транспорт, тяговый электропривод, электрическое торможение, электродвигатель, преобразователь постоянного тока, тормозной резистор

Для цитирования: Повышение энергетических характеристик тяговых электромобилей в решении проблемы электрического торможения / В. Герасименко [и др.] // Наука и техника. 2021. Т. 20, № 1. С. 52-57. https://doi.org/10. 21122/2227-1031-2021-20-1-52-57

\section{Introduction}

Traction electric drives are introduced more and more every year in transport. They are used in urban electric vehicles, mining trucks, hybrid cars, electric cars, electric buses and other modes of transport. At the same time, the dynamic, energy and environmental performance of vehicles is significantly improved, it becomes possible to realize greater power and carrying capacity on mining trucks, introduce electric braking instead of mechanical, and use a mechanical brake as a backup. With electrical braking, it is possible not only to extinguish the electric energy on the braking resistor, but also, if possible, send it back to the power source or drive and use it again in traction mode. The effectiveness of the electric braking system largely depends on how the braking is carried out, whether the braking characteristics that it forms are acceptable for a given vehicle, how simple and reliable the technical solutions embedded in the system are, and where the braking energy is used.

\section{Literature review}

Significant attention is being paid to improving the energy and environmental performance of vehicles, not only in the EU, but throughout the world.

In [1], the use of various concepts of traction drives in the Czech Republic and in the world is discussed and evaluated, the advantages and disadvantages of the new concept and the possibility of using systems with outdated types are evaluated.

In [2], the possibilities for reducing electricity consumption in electric systems of urban public transport using audit of their electric system were identified. To substantiate the importance of these problems, a mathematical model of the energy balance of the electric system of urban public transport and its components is presented.

In $[3,4]$, an improvement in the energy performance of traction electric drive systems of tram cars in some cities of Ukraine was shown to be up to $35 \%$ due to the introduction of electrical equipment such as "TV Progress" based on a pulse converter from ALSTOM.
In the Republic of Belarus, trams, trolleybuses, electric buses are produced in large quantities for urban electric vehicles with a modern traction electric drive, which has a positive effect on the ecology of cities and energy conservation of resources. Requirements to increase the reliability of transport and reduce operating costs dictate the need for modern traction control systems for electric drives in urban electric vehicles. The use of transistor control systems for traction motors can significantly increase efficiency by reducing energy consumption, reducing maintenance costs and reducing downtime of mobile units [5].

The issues of reforming urban electric transport in Ukraine are determined by the State program for its development [6]. There are two ways to solve them. The first is the use of pulsed DC-DC-converters on a modern elemental base with a microprocessor control system and standard traction DC electric motors of sequential excitation. This is a more economical option. The second way is the use of autonomous voltage inverters with traction asynchronous electric motors and a microprocessor control system. In Ukraine, the use of pulse converters has become more widespread in urban electric transport. This is because tram cars of the T3M type are operated with pulse converters [7].

Given that in Ukraine, most urban electric vehicles are equipped with a traction electric drive with DC motors with sequential excitation and obsolete brake equipment, the issues of improving the electric braking system of these vehicles and improving their energy performance are very relevant.

\section{Research methodology}

The most common methods of electric braking used in electric braking systems of traction electric drives that are in operation on vehicles are analyzed. As the main criterion in assessing the method of electric braking, its energy indicators are selected. A comparative analysis should also be guided by the following criteria:

- compliance with modern technical requirements; 
- modernization costs;

- operating costs;

- reliability;

- unification of electrical equipment.

\section{Description}

An analysis of electric braking systems that use sequential excitation DC motors has shown that one of the most common braking methods is the method in which the motors operate with independent excitation DC generators [8]. The excitation windings are powered from an adjustable voltage source that receives energy from the network, and the anchor windings are shorted to brake resistors. Braking energy is dissipated on the braking resistors in the form of heat. Such an electric braking system provides reliable entry into the braking mode, allows you to generate braking characteristics with constant force for equidistant motion, which is very important for an exact stop. This ensures restrictions on the maximum speed, switching ability of traction motors, adhesion and maximum excitation current.

The disadvantages of this braking method include the low braking efficiency at low speeds, the energy consumption from the network for excitation, and the dissipation of all braking energy on the braking resistors in the form of heat. In addition, when the network is de-energized, electrical braking is generally impossible.

There is also known a method of electrical braking, in which traction motors operate as sequential excitation generators and the electrical energy obtained during braking is dissipated in the form of heat on braking resistors [9]. Generators are excited by self-excitation. The braking system generates characteristics that are more suitable for braking on a slope than for stopping. For stopping braking, the resistance of the braking resistors is gradually reduced.

The disadvantages of this method of braking should include low energy indicators, since all braking energy is extinguished on the braking resistors, as well as entering the braking mode with delay in the low-speed region. To accelerate the self-excitation of traction motors in the generator mode, use additional power to the field windings from the battery or use a parallel field winding.

A combined method of electric braking and a variable structure electric braking system are proposed, which provide braking at the initial stage as with sequential excitation generators, followed by automatic regulation of the excitation current of the generators using a DC-DC converter by shunting the drive excitation windings of electric motors with the input of this converter [10]. In this case, braking characteristics are formed with constant force, there is no need to consume electric energy from the network to excite electric motors, and the energy from the converter output can be used for your own needs.

To increase the braking efficiency at low speeds, it is necessary to regulate smoothly the resistance of the braking resistors by shunting them with transistor switches.

To effectively enter the braking mode, the following is proposed. Considering that the electromotive force of the engine in the generator mode is proportional to the magnetic flux and revolutions $E=C \Phi n$, it is necessary to apply a pulse from the DC-DC-converter in the initial stage of braking, inversely proportional to the speed of the engine speed.

The operation of the braking system with a variable structure is explained by the circuit shown in Fig. 1.

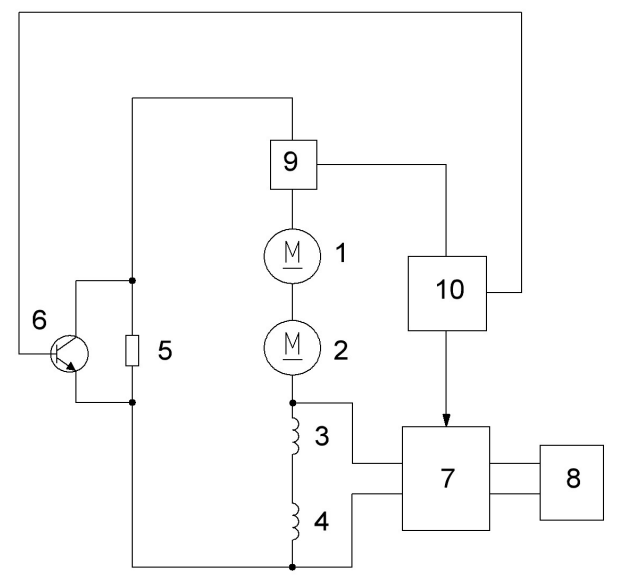

Fig. 1. Functional diagram of a variable structure braking system

The scheme works as follows. When switching to electric braking mode, the automatic control system 10 includes a transistor switch 6 , while the anchor windings 1,2 and the excitation windings 3, 4 of the electric motors are turned on as in sequential excitation generators and are shortcircuited. Due to the residual magnetization in the field windings 3,4 , on the armature windings 1,2 , 
an electromotive force will appear, under the action of which a current will flow, which is measured by the current sensor 9. After the current reaches the set value, the automatic control system 10 turns off the transistor switch 6 and turns on DC-DC-converter 7, which shunts the excitation windings 3, 4 with its input and regulates the magnitude of the current through the excitation windings 3, 4, as with independent excitation of electric motors. In this case, the DC-DC-converter 7 gives off electric energy to its own needs 8 . In the low-speed zone, to increase the braking efficiency, the automatic control system 10 turns on the transistor switch 6 and puts it into pulse-width modulation mode, while the equivalent resistance of the braking resistor decreases and expands area of effective braking at low speeds.

To implement the proposed method, the structure of the braking system is required, in which the current in the field windings during braking does not change direction. For this purpose, the structure described in $[11,12]$ is most suitable, where the pulse converter is made according to the scheme of a single-phase transistor bridge with reverse diodes, the diagonal of which includes series-connected anchor windings of electric motors for reversing the direction of movement (Fig. 2).

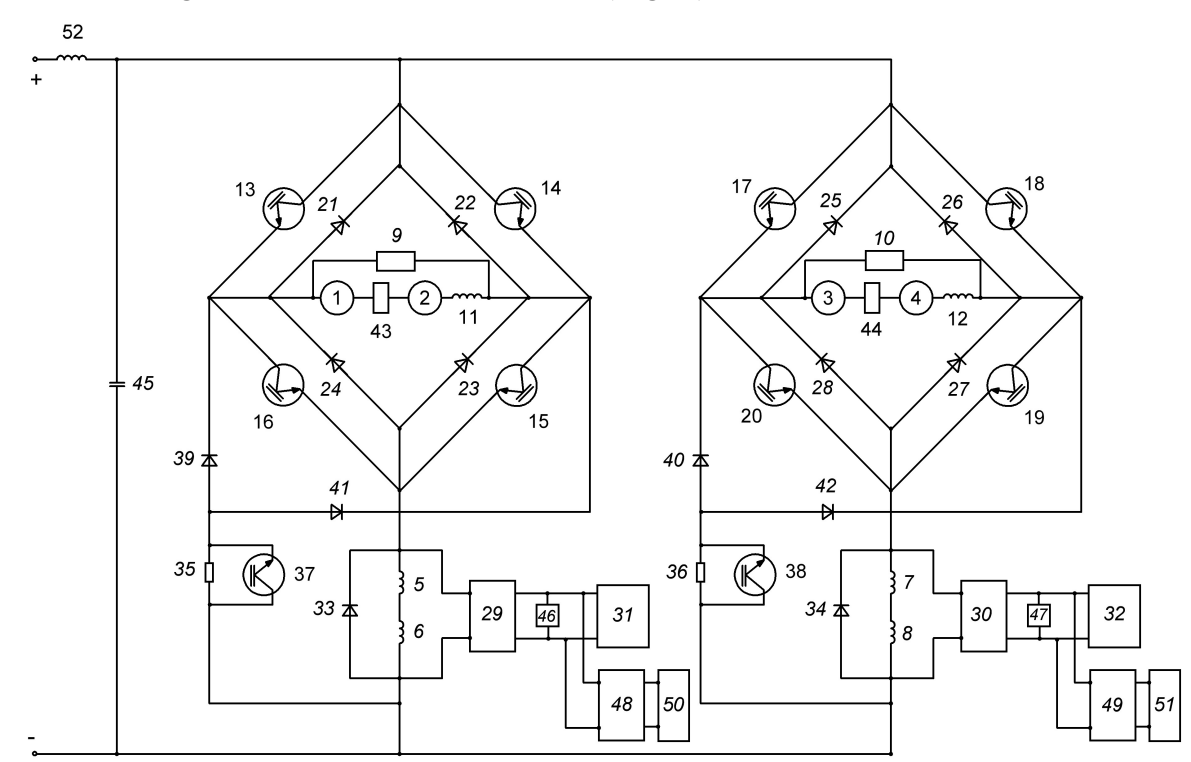

Fig. 2. Diagram of an electric braking system with a variable structure verter duty cycle.

windings of the electric motors 1,2 and 3, 4 and the field windings 5, 6 and 7, 8, the first DC-DCconverters 29,30 to regulate the current through the field windings 5,6 and 7,8 and turn off the transistors 37,38 . In this case, the mode of electrical resistive braking occurs and part of the energy through the first DC-DC-converters 29, 30 goes to energy storage 31,32 and through other DC-DCconverters 48,49 to the chains of their own needs 50,51 . At the same time formed as a braking performance from an independent generator excitation. In the low-speed range, transistors 37, 38 turn on and go into pulse-width modulation mode to increase braking efficiency.

Let us determine the relationship between the parameters of the DC-DC-converter of the proposed circuit and the coefficient of regulation of the excitation of the traction motor.

Based on [13], for a DC-DC-converter, the ratio

$$
U_{O U T}=\frac{U_{I N}}{1-\gamma},
$$

where $U_{\text {OUT }}$ - DC-DC-converter output voltage; $U_{I N}$ - converter input voltage, which corresponds to the voltage drop across the series excitation winding of the traction motor; $\gamma-$ DC-DC-con-

In accordance with the law of conservation of energy, the following can be written:

$$
I_{I N} U_{I N}=I_{O U T} U_{O U T} K_{D C},
$$

where $I_{I N}, I_{O U T}$ - respectively, the input and output current of the DC-DC-converter; $K_{D C}-$ converter efficiency.

We substitute in the expression (2) the value of the output voltage of the converter

$$
I_{I N} U_{I N}=I_{\text {OUT }} \frac{U_{I N}}{1-\gamma} K_{D C} \text {. }
$$

In accordance with the scheme of the device, the output current of the DC-DCconverter is equal to

$$
I_{\text {OUT }}=\frac{1-\gamma}{K_{D C}} I_{I N} .
$$

The scheme works as follows. In the "Braking" mode, when the vehicle moves in the "Forward" direction, transistors 15,19 and 37,38 are turned on. After the current flows through the armature
In expression (4), you can replace the input current of the DC-DC-converter with the expres$\operatorname{sion}\left(I_{A}-I_{F}\right)$ 


$$
I_{\text {OUT }}=\left(I_{A}-I_{F}\right) \frac{1-\gamma}{K_{D C}},
$$

where $I_{A}, I_{F}$ - respectively, the current of the anchor winding and the field winding of the traction motor.

Dividing expression (5) by the current of the armature of the traction motor, we obtain

$$
\frac{I_{F}}{I_{A}}(1-\gamma)=(1-\gamma)-\frac{I_{O U T} K_{D C}}{I_{A}} .
$$

Since the ratio of the currents of the field winding and the anchor winding of the traction motor is equal to the coefficient of regulation of its excitation

$$
\frac{I_{F}}{I_{A}}=\alpha,
$$

the coefficient of regulation of the excitation of the traction motor is equal to

$$
\alpha=\frac{(1-\gamma)-\frac{I_{O U T}}{I_{A}} K_{D C}}{1-\gamma} .
$$

Based on the fact that the ratio of the output current of the DC-DC-converter $I_{O U T}$ to the current of the anchor winding of the traction motor $I_{A}$ is equal to the load factor of the DC-DC-converter $K_{L}$, we finally obtain the expression for the coefficient of regulation of the excitation of the traction motor

$$
\alpha=\frac{(1-\gamma)-K_{L} K_{D C}}{1-\gamma} .
$$

Based on expression (9), the dependences of the change in the coefficient of regulation of the excitation of the traction electric motor $\alpha$ on the fill factor of the DC-DC-converter $\gamma$ for various values of $K_{L}$ and $K_{D C}=0.9$ are constructed. These dependencies are presented in Fig. 3.

From the characteristics shown in Fig. 3, it can be seen that they are non-linear. With decreasing load factor of the DC-DC-converter $K_{L}$, the nonlinearity increases. Given that in practice the coefficient of regulation of the excitation of the traction motor $\alpha$ is not realized below a value of 0.3 , it is possible to determine the working area for the traction motor in the electric braking mode. The working area when using the proposed method for a traction motor in electric braking mode is limited by the value of the load factor $K_{L}=0.1$, the value of the excitation regulation coefficient $\alpha=0.3$ and the value of the load factor $K_{L}=0.5$.

Further improvement of the electric braking system with a variable structure is possible due to the accumulation of braking energy of the power circuit in the drives with its subsequent use in traction mode. Such a technical solution is shown in Fig. 4.

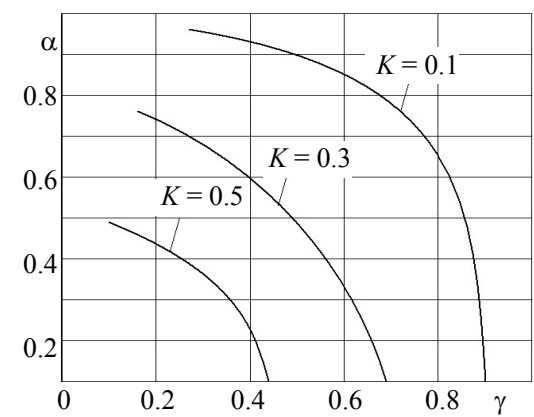

Fig. 3. The dependence of the coefficient of regulation of the excitation of the traction motor $\alpha$ from the fill factor DC-DC-converter $\gamma$

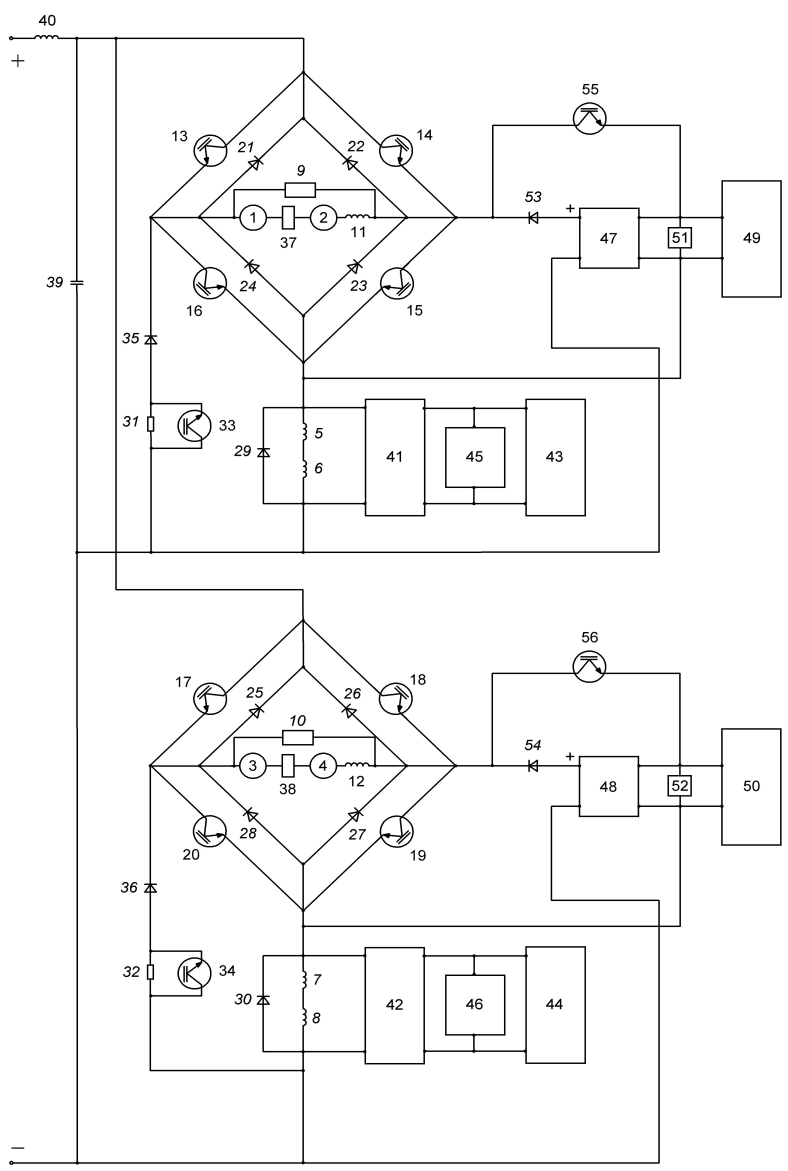

Fig. 4. An improved diagram of an electric braking system with a variable structure

An improved circuit of the electric braking system with a variable structure works as follows.

When the electric braking mode is switched on, transistors 15 and 19,33 and 34 are turned on. In this case, the armature windings 1 and 2 and the field windings 5 and 6 of the motors, as well as the anchor windings 3 and 4 and the field windings 7 
and 8 are turned on as sequential field generators and shorted between each other shortly.

Due to the residual magnetization in the field windings 5, 6 and 7, 8, an electromotive force will appear on the armature windings 1, 2 and 3, 4, under the influence of which a current will flow, which is measured by current sensors 37 and 38 . After the current reaches the set value, the transistors 15 and 19 and turn on transistors 55, 56, as well as the first DC-DC converters 41 and 42 . Braking current will flow through transistors 55 and 56, the inputs of the second drives 49 and 50, the field windings 5, 6 and 7, 8, transistors 33, 34 and motor anchors 1,2 , and 3, 4. The first DC-DCconverters 41 and 42 by their inputs bypass the field windings 5, 6, and 7,8, and thereby regulate the current in them as if the independent excitation of the electric motors. From the outputs of the first DC-DC-converters 41 and 42, energy is supplied to the first drives 43 and 44 and used for their own needs. If other drives 49 and 50 are full and braking continues, the transistors 55 and 56, 33 and 34 turn off and the transistors 15, 19 turn on and the braking energy is converted into heat on the braking resistors 31 and 32. In the low-speed zone, transistors 33 and 34 go into pulse-width modulation mode and reduce the equivalent braking resistance, provides effective braking. In this case, braking characteristics are formed as in independent excitation generators. The energy stored in storage 49,50 is used in traction mode.

\section{CONCLUSIONS}

1. The analysis of the most common methods of electric braking of vehicles is carried out, on the basis of which a combined method and a system of electric braking with a variable structure are proposed.

2. When implementing this method, DC motors operate as sequential excitation generators. The current in the field windings is regulated using a DCDC-converter. Energy in the power circuit is accumulated in the drives and then used in traction mode. When the drives are full, the energy in the power circuit is extinguished by the brake resistor, and the energy from the output of the DC-DC-converter is used for own needs. In this case, braking characteristics are formed as in independent excitation generators.

3 . The proposed method has significantly improved the energy performance of the electric braking system.

\section{REFERENCES}

1. Veg L., Laksar J., Pechanek R. (2017) Overview of Different Concepts of Traction Drives with Regard to High-Speed PMSM. $18^{\text {th }}$ International Scientific Conference on Electric Power Engineering (EPE), 1-5. https://doi.org/10.1109/ EPE.2017.7967236.
2. Felea I., Csuzi I., Barla E. (2013) Modelling and Assessing Energy Performance of an Urban Transport System with Electric Drives. Promet - Traffic \& Transportation, 25 (5), 495-506. https://doi.org/10.7307/ptt.v25i5.1207.

3. Cerny M., Kachimov V. (2009) Introduction of EnergyEfficient Equipment and Technologies on the Rolling Stock of Urban Electric Transport of Ukraine. Коттиnal'noe Khozyaistvo Gorodov [Communal Services of Cities], 88, 263-268 (in Russian).

4. Cerny M., Kachimov V. (2009) Introduction of EnergyEfficient Equipment and Technologies on the Rolling Stock of Urban Electric Vehicles of Ukraine. Stalii Rozvitok Mist. Elektrichnii Transport - Perspektivi Rozvitku ta Kadrove Zabezpechennya [Staliy Rozvitok Mist. Electric Transport Prospects for Development and Personnel Security: Materials of the International Science-Practical Conference]. Kharkiv, KHNAMG, 58-59 (in Russian).

5. Kazachenko V. V. (2017) Energy Optimization of Traction Electric Drives. Issledovaniya i Razrabotki v Oblasti Mashinostroeniya, Energetiki i Upravleniya: Materialy XVII Mezhdunar. Nauch.-Tekhn. Konf. Studentov, Aspirantov i Molodykh Uchenykh, Gomel', 27-28 Apr. 2017 g. [Research and Development in the Field of Mechanical Engineering, Energy and Management: Materials of the XVII Intern. Scientific and Technical Conf. Students, Graduate Students and Young Scientists, Gomel, April 27-28, 2017]. Gomel, Sukhoi State Technical University of Gomel, 308-311 (in Russian).

6. Kramarenko R. M. (2008) Stan and the Main Lines of Convenience to the Robots of Moscow Electric Transport in the Minds of Today. [International Conference and Technical Exhibition: "Moscow Electric Transport. Protection of the Steel Function and Development"]. Zbirka Dopoviday. Yalta, 8-18 (in Russian).

7. Electrical Equipment of the T6V5 Tram Car - (T3M). Prague, CKD Publ., 1982. 310.

8. Tulupov V. D. (1976) Automatic Control of Traction and Braking Forces of Electric Rolling Stock. Moscow, Transport Publ., 136-138 (in Russian).

9. Tikhmenev B. N., Trakhtman L. M. (1980) Rolling Stock of Electrified Railways. Theory of Electrical Equipment. Electric Circuits and Devices. Moscow, Transport Publ., 147-151 (in Russian).

10. Gerasimenko V. A., Shpika M. I. (2018) The Method of Automatic Control of Traction Motors of Series Excitation in the Mode of Electric Braking. Patent of Ukraine No 126978 (in Ukrainian).

11. Shpika N. I., Andreichenko V. P., Besarab A. I. (2015) Improving the Technical Efficiency and Energy Performance of the Traction Electric System of a Tram Car. Zbirnik Naukovikh Prats' Ukraïns'kogo Derzhavnogo Universitetu Zaliznichnogo Transportu = Collection of Scientific WORKS of Ukrainian State University of Railway Transport, 153, 90-98 (in Ukrainian).

12. Besarab A. I., Shpika M. I., Andriychenko V. P., Khvorost M. V. (2015) Control Device for Traction Electric Motors of Sequential Excitation of Electric Rolling Stock. Patent of Ukraine No 101885 (in Ukrainian).

13. Shpika N. I., Andreichenko V. P., Gerasimenko V. A. (2015) Improving the Methods for Controlling the Speed of Traction DC Motors of Sequential Excitation. Zbirnik Naukovikh Prats' Ukraïns 'kogo Derzhavnogo Universitetu Zaliznichnogo Transportu = Collection of Scientific WORKS of Ukrainian State University of Railway Transport, 153, 84-90 (in Ukrainian).

Received: 08.10.2019

Accepted: 10.12.2019 Published online: 29.01.2021 